\title{
Specificity of the Gospel of Mark as Interpreted by Theophylact of Ohrid
}

\author{
MONIKA CZARNUCH-SODZAWICZNY \\ University of Silesia in Katowice \\ monika.czarnuch-sodzawiczny@us.edu.pl, ORCID: 0000-0002-2135-5367
}

\begin{abstract}
While Theophylact's Enarratio in Evangelium Marci [Explanation of the Gospel of Mark] is known as the first commentary on the whole Gospel in Greek, the question remains: how much of Mark's Gospel is in this Explanation? The main aim of the article is to examine whether Theophylact notices the specificity of Mark's Gospel, or whether he is harmonizing Mark with Matthew, on which he commented earlier, or other Gospels. The analysis of the Explanation of the Gospel of Mark shows that Theophylact relates to content typical of the Gospel of Mark. He distinguishes Mark's theology from other Gospels, recognizing at the same time the theological unity of the four Gospels. His attentiveness to the details of the narrative is evidenced by the accurate presentation of divergences and, regarding some pericopes, the lack of harmonization.
\end{abstract}

Keywords: Theophylact of Ohrid, Gospel of Mark, Biblical commentaries, Wirkungsgeschichte

Nowadays, when so many excellent commentaries on Mark's Gospel are available, does a study of the 11th-century explanation have any value in interpreting this Gospel? The fact that Theophylact's Enarratio in Evangelium Marci [Explanation of the Gospel of Mark] is the first commentary on the whole Gospel in Greek might be a sufficient reason for examining it. The role of this commentary in the transmission of the Gospel text and in the spread of Chrysostom's homilies is also important. Above all, however, the value of the Explanation of the Gospel of Mark is demonstrated by Theophylact's originality in his approach to Mark. The Bishop of Ohrid undertakes commenting on Mark, although he previously presented his interpretation of the Gospel of Matthew. Such an attention to the texts of the individual Gospels is eight centuries ahead of the breakthrough in New Testament exegesis ${ }^{1}$.

The project was financed by the National Science Center in Krakow, granted on the basis of decision number DEC-2014/13/N/HS1/02054. The article presents the results of the research, part of which was published in: Czarnuch, Ewangelia Marka w komentarzu Teofylakta.

1 The effect of the development of studies on the Gospel of Mark from the end of the $19^{\text {th }}$ century is the recognition of its value for diachronic exegesis (due to the priority of Mark among synoptics and the influence on the formation of the synoptic tradition, and due to the closeness to historical Jesus); its literary and theological features have also been noted. Meanwhile, Theophylact seems to have been the first to interpret Mark for values appreciated in the synchronic and theological approaches. 
No one before Theophylact either explained the entire Gospel of Mark or did it consistently. Although his commentaries on the four Gospels have recently been made available in English, ${ }^{2}$ there is still no satisfactory critical edition of them. Perhaps for this reason, ${ }^{3}$ there is no adequate scholarly discussion about Theophylact's Explanations, their sources, and meaning for biblical studies. ${ }^{4}$ Even if any references to the commentaries of the Bishop of Ohrid appear, they are rather perfunctory. ${ }^{5}$ There is a belief that his text is dependent on Catena in Marcum and on John Chrysostom's interpretation of Matthew, although the relationship between the texts of both authors has not been fully investigated so far, and the Bishop of Ohrid comments on texts which John Chrysostom did not interpret. ${ }^{6}$

The main aim of the article is to examine how Theophylact relates to Mark's text. Does he notice the specificity of Mark's Gospel? Does he see the differences between parallel pericopes, and how does he explain them? Is he faithful to Mark or is he harmonizing with the already commented on Matthew or another Gospel?

The article presents the results of the analysis of the Explanation of the Gospel of Mark, referring to the content typical of the Markan Gospel. Firstly, it discusses examples of explanations in which Theophylact compares the Gospel of Mark with other Gospels. Then, it presents those fragments of the commentary in which the Bishop of Ohrid ascribes the authorship of a given Gospel fragment to Mark. Finally, it cites examples of such explanations, in which Theophylact refers to words, expressions, and pericopes absent in other Gospels, although he does not indicate that they are specific to Mark. It is beyond the scope of the research to compare Theophylact's comments on Markan-Matthean parallels and to assess whether Theophylact's interpretation of Mark influenced his explanations of other Gospels.

\section{Comparison of Mark's Gospel with Others}

Theophylact, commenting on the Gospel of Mark, compares its content with that of other Gospels. ${ }^{7}$ He includes reflections on the necessity of the creation of four Gos-

2 Stade, Matthew; Stade, Mark; Stade, Luke; Stade, John.

3 Opinions about Theophylact, adopted without sufficient verification, can also be taken into consideration cf. Czarnuch, "Papuga Złotoustego?," 36-40.

4 Comprehensively on the need and possibilities for research in Theophylact's works in: Brown, "The Gospel Commentary," 194-196.

5 There are some references to Theophylact in contemporary commentaries on the Gospel of Mark. A list of these can be found in: Czarnuch, Ewangelia Marka, 14.

6 The author of this article is preparing a paper on the comparison of the commentaries of Theophylact, John Chrysostom and "Catena in Marcum" on four verses of the Gospel of Mark.

7 In the "Explanation of the Gospel of Mark," 28 places were found in which Theophylact juxtaposes the Gospel of Mark with other Gospels. 
pels already in the "Preface" to the Explanation of the Gospel of Matthew. ${ }^{8}$ He states that although one evangelist would suffice, four convey the truth better. In the opinion of the Bishop of Ohrid, the agreement of the four Gospels testifies to its truth and origin from the Holy Spirit.

The Bishop of Ohrid emphasizes the convergence of the Gospels in his emotional words: "Don't tell me that they don't harmonize with anything! See what they don't harmonize with. While this one said Christ was born, this one said he was not? Or this one - that he was risen, and this one - that he was not? Meanwhile, it is not so, because they are in harmony about the most essential and the most important facts." According to Theophylact, even the differences between the Gospels confirm that the evangelists tell the truth: "So if they do not differ in the most important, why are you surprised if they seem to change in the smallest things? Because of this, they tell the truth even more, because they are not in harmony about everything." 10 The Bishop of Ohrid states that if the differences didn't exist, one might think that the evangelists wrote the Gospels after consulting one another. At the same time, he notes that the evangelists "seem to change in the smallest things" in their Gospels, suggesting that contradictions between the Gospels are just an illusion.

Evidence of this approach can also be found in the Explanation of the Gospel of Mark.

\subsection{The Harmonization of Differences}

The issue of the harmony of the Gospels, despite the differences between them, mentioned in the "Preface to the Explanation of the Gospel of Matthew," is also taken up by Theophylact in the Explanation of the Gospel of Mark. Commenting on the beginning of the narrative about the transfiguration of Jesus (Mark 9:1-2), ${ }^{11}$ Theophylact notes that Luke places these events "after eight days," including both the previous day, when Jesus was called the Messiah, and the day when he led the disciples to the mountain. Mark, in turn, speaks of the six days that are in between. According to Theophylact, the Evangelists not only do not contradict each other, but are even in harmony with each other. The Bishop of Ohrid, noting the differences between the pericopes, gives a harmonizing explanation, in which he emphasizes that the reference to six days, compared to the Gospel of Luke which speaks of eight days, occurs in the Gospel of Mark. Theophylact does not mention here the Gospel of Matthew,

\footnotetext{
Theophylactos, Enarratio in Evangelium Matthaei (PG 123, 144-148).

Theophylactos, Enarratio in Evangelium Matthaei (PG 123, 148).

Theophylactos, Enarratio in Evangelium Matthaei (PG 123, 148).

Theophylactos, Enarratio in Evangelium Marci (PG 123, 580).
} 
which also places the transformation "after six days" (Matt 17:1) and refers only to the text of Mark.

Theophylact states, with regard to some pericopes, that the Gospels describe various elements of the same event. Theophylact harmonizes the Gospel of Mark not only with Matthew, but also with the pericopes of Luke and John, to show the lack of contradiction between the Gospels. In the commentary to the pericope of the calling of Levi (Mark 2:13-17), ${ }^{12}$ Theophylact aptly notices the difference between the parallel pericopes, regarding the name of the person called (Mark 2:14 has "Levi (the son) of Alphaeus," Luke 5:27: "Levi," and Matt 9:9: "Matthew"). Theophylact states that the publican appointed by Jesus had a double name, although the evangelists say it differently: Luke and Mark hide his name, calling him Levi, while Matthew is not ashamed to testify about himself. ${ }^{13}$ When commenting on the pericope about Simon of Cyrene (Mark 15:16-21), ${ }^{14}$ the Bishop of Ohrid states that at first Jesus probably carried his cross alone (as the "other evangelist" said, Theophylact does not specify that he refers to John 19:17), and then Simon was forced to carry Jesus' cross: so both events took place. In turn, in the commentary on Mark 15:29-32, Theophylact refers to the words of Mark: "And those, who had been crucified with him, were reviling." ${ }^{15} \mathrm{He}$ explains that at first the two crucified insulted Jesus, but later, as Luke mentions, when one of them recognized that Jesus was innocent, he admonished the other blasphemer.

Theophylact comments in a similar way on the narrative about the expulsion of sellers and buyers from the temple (Mark 11:15-18), ${ }^{16}$ juxtaposing it with the pericope of the Gospel of John (John 2:13-16). The Bishop of Ohrid explains that it probably happened twice, as John writes about it at the beginning of the Gospel, and Mark at the end. Theophylact does not discuss the fact that the expulsion of sellers and buyers is also found at the end of the Gospels of Matthew and Luke. The Bishop of Ohrid does not refer to the mention of the ban on moving equipment through the temple, which is characteristic only of Mark. ${ }^{17}$ Thus, the explanation here is far from the content of Mark, although Theophylact accurately notices the difference between Mark and John in the location of this pericope.

Theophylact, in view of some pericopes of Mark, draws attention to the need for appropriate reading of the text to understand it properly. Theophylact, analyzing

12 Theophylactos, Enarratio in Evangelium Marci (PG 123, 513-516).

13 Theophylact, however, does not refer to the term "son of Alphaeus," found only in Mark.

14 Theophylactos, Enarratio in Evangelium Marci (PG 123, 665).

15 Theophylactos, Enarratio in Evangelium Marci (PG 123, 669).

16 Theophylactos, Enarratio in Evangelium Marci (PG 123, 616).

17 Theophylact in his commentary refers to some elements of the narrative: he explains what "robbers' cave" means, and who the "money changers" were. He gives allegorical meaning to several elements ("selling and buying," "tables and benches," as well as "pigeons"). However, these elements are found in the Gospels of both Mark and Matthew. 
the beginning of the pericope about the meaning of faith and prayer (Mark 11:19-23), ${ }^{18}$ strives to reconcile the observation made by Matthew: "the fig tree withered immediately, and the disciples were amazed when they saw it" (Matt 21:19-20) with Mark's sentence: "And in the morning as they passed by, they saw the fig tree withered to its roots" (Mark 11:20). The Bishop of Ohrid explains that the fig withered immediately after Jesus' words (as Matthew testifies), but the disciples did not notice it until the next day (as Mark writes). Therefore, Theophylact aptly notices the specificity of the Markan Gospel in the explanation of the pericope, ${ }^{19}$ although he harmonizes the stories of Matthew and Mark.

\subsection{Discussion on the Differences}

In the explanations of some pericopes of Mark's Gospel, Theophylact discusses the differences between the Gospels and notices the contents typical of Mark, but he does not harmonize them.

In the commentary to the story about the healing of the paralytic carried by the four (Mark 2:1-5), ${ }^{20}$ Theophylact lists the differences between this narrative and the pericope about the sick by a pond from the Gospel of John (John 5:1-9). He observes that the sick man described by John "had no man" and was by the pond in Jerusalem, while, according to Mark, he had four people and was at home in Capernaum. ${ }^{21}$ The elements of Mark's narrative distinguished by Theophylact (the four carrying the sick one, and the double definition of the place of action: in Capernaum and at home) are characteristic only of this Gospel.

The originality of this explanation can be seen in its juxtaposition with John Chrysostom's commentary on the parallel pericope in the Gospel of Matthew (Matt 9:1-8). The Golden mouthed one lists several differences between Matthew's and Mark's pericopes, which are not included in Theophylact's commentary. ${ }^{22}$ More-

18 Theophylactos, Enarratio in Evangelium Marci (PG 123, 616-617).

19 Theophylact emphasizes in his explanation, the relationship between the words of Jesus and the state of the fig, which occurs in Mark, but does not refer to the immediacy of events, characteristic of Matthew

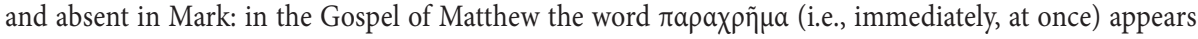
twice in proximity; Matt 21:19b.20

20 Theophylactos, Enarratio in Evangelium Marci (PG 123, 509-512).

21 Theophylact gives an allegorical interpretation of the name of the place. Christ is present also now

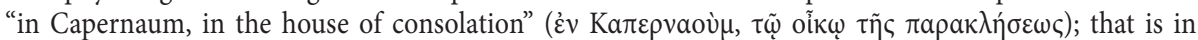

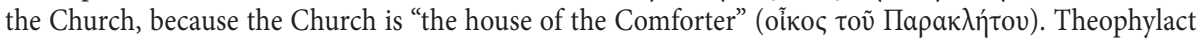
knows the Semitic meaning of the name of the place. Moreover, he does not stop at mentioning it. He explains that the "house of consolation" means the "house of the Comforter." Such a remark may be a reference to the Gospel of John, in which Jesus is described as the Comforter.

22 Firstly, the sick one described by John has been suffering for thirty-eight years, while Matthew does not mention the duration of the illness. Secondly, the words of Jesus to the sick one are different in 
over, Chrysostom highlights two features of the narrative which are also mentioned by the Bishop of Ohrid.

Firstly, both commentators likewise emphasize the differences in the way the evangelists described those who brought the paralyzed one. The Golden mouthed one explains that the sick person described by John "had no one to help him," but, according to Matthew, "he has those who care for him and even brought him.. ${ }^{23}$ Theophylact, on the other hand, states: "While this one in John had no man, that one has four."

Secondly, both commentators, each slightly differently, refer to the place of the action. Chrysostom explains that, according to John, the sick person is lying by the pond, while according to Matthew, the sick one is in Capernaum. ${ }^{24}$ Theophylact, on the other hand, determines the place in two ways. Firstly, he indicates that the patient described by John is by the pond, and the one described by Mark is at home. Then, he notes that the former is in Jerusalem, and the latter is in Capernaum. Thus, even if the Bishop of Ohrid takes the Golden mouthed one's comparison with the pericope of John, he refers to those features of the narrative which appear in the Gospel of Mark and only in it, i.e., the four bearers of the sick one and the double definition of the place of action: Capernaum and the house.

Considering the identity of the woman who came to Jesus with the alabaster vessel of nard oil (Mark 14:1-5), ${ }^{25}$ Theophylact points out that, according to some, ${ }^{26}$ all the evangelists describe the same woman. However, he explains that there were two different women: the first one, the sister of Lazarus, is described by John, and the second one by the other evangelists. He also adds that, thanks to mindfulness, one can even see three women: one is described by John, another, who was a prostitute and came to Jesus during his public ministry, is presented by Luke, and the third, who came to Jesus before the Passion and was not called a prostitute, is mentioned by the other two evangelists.

Theophylact accurately outlines the differences between the parallel narratives. He also notices the relationship between the term for the woman, the place, and the meaning of this pericope throughout the Gospel. Matthew and Mark place this pericope (Matt 26:6-13; Mark 14:3-9) between the mention of the council of the Jewish superiors who wanted to seize and kill Jesus (Matt 26:1-5; Mark 14:1-2)

the messages of John and Matthew, because in John Jesus asks: "Do you want to be healthy?, while in Matthew he says: "Trust, son, your sins are forgiven"). Thirdly, the time of the events is different: for John, the healing was performed on the Sabbath, while for Matthew not.

23 Ioannes Chrysostomus, Commentarius in Sanctum Matthaeum Evangelistam, Homilia 29,1 (PG 57, 357-362).

24 The Gospel of Matthew does not say that the scene takes place in Capernaum, but that Jesus returned to "his city" (Matt 9:1). Chrysostom begins his commentary on this pericope by explaining that Capernaum should be regarded as the above-mentioned place.

25 Theophylactos, Enarratio in Evangelium Marci (PG 123, 644-645).

26 It is possible to notice here a reference to the sources used by Theophylact, although unfortunately in the "Explanation" there is no precise definition of these "some." 
and the betrayal of Judas (Matt 26:14-16; Mark 14:10-11). The act performed by the woman, which Jesus defined as the anointing of his body for burial, is significant in this context. Theophylact draws attention to the relationship between the accomplished anointing and the impending torment. Such an explanation, although accurate in the context of Mark's Gospel, also corresponds with Matthew's narrative. ${ }^{27}$

In the commentary on the pericope about Peter's denial (Mark 14:66-72), ${ }^{28}$ Theophylact notices the difference between Matthew, who tells about two servants revealing Peter, and Mark, who mentions only one. The Bishop of Ohrid states that the number of servants is neither an important issue nor related to salvation, so this discrepancy does not harm the truth of the Gospel. Such an explanation corresponds to Theophylact's expression in the "Preface to the Gospel of Matthew."

In the commentary on the pericope about the appearance of the Risen One (Mark 16:9-14), ${ }^{29}$ the Bishop of Ohrid refers to the description, which can be found only in Mark, of Jesus' coming "in a different form" to two people going to the village. He recalls Luke, who also tells of how Jesus appeared in a different guise to two walking disciples. Theophylact, however, draws attention to the differences between these narratives: in Mark, there were two of the disciples, who told the others, but the latter did not believe them. According to Luke, in turn, two of the disciples met the eleven, saying that the Lord was risen. According to Theophylact, "the others," mentioned by Mark, who disbelieved are not among the same group that Luke calls "the Eleven." This explanation is in accordance with Mark's narrative: Jesus at first appears to Mary Magdalene, who announces "to those who were with him," then he shows himself to "two of them," who announce this fact to the rest, and finally, he appears to the Eleven. The term "those who were with him" indeed recalls the first task of the Twelve (Mark 3:14). However, it is possible that Mark refers to a larger group of disciples than the Twelve. ${ }^{30}$ Theophylact, therefore, accurately shows the differences between the narratives and comments on them in conformity with the Gospel of Mark.

27 Moreover, in the further part of the commentary on this pericope, Theophylact moves away from the content of the Markan Gospel. He notes that according to Mark, "there were some people who were outraged" (Mark 14:4), while according to John, it was Judas who was indignant. He adds that probably other apostles also admonished the woman, because they always heard Christ teaching about alms, but Judas' behavior was due to his love of money and his greed. Such a harmonizing explanation is not in line with the Markan Gospel. It is the Gospel of Matthew that presents the apostles as outraged by the actions of the woman and explicitly describes Jesus' teaching on alms (Matt 6:2-4). Thus, Theophylact in this explanation distances himself from the content of Mark.

28 Theophylactos, Enarratio in Evangelium Marci (PG 123, 661-664).

29 Theophylactos, Enarratio in Evangelium Marci (PG 123, 677-680).

30 According to Mark, the expression "those with him" (oi $\mu \varepsilon \tau$ ' av่toṽ) also refers to those accompanying Peter (Mark 1:36), David (Mark 2:25) and Jesus (Mark 5:40). The function of the prepositional phrase "A with B" in the Gospel of Mark in: Malina, "Dlaczego Jezus był ze zwierzętami," 243-246. 


\section{Clear References to the Gospel of Mark}

Theophylact explicitly refers to this Gospel in eleven places in the Explanations. He does not compare it with parallel pericopes but emphasizes the origin of the explained expression from Mark the Evangelist. He most often uses expressions such as: "Mark says / tells / names," "The Evangelist speaks / names," but also "Mark remained silent" and "Mark inserts a story." In such explanations, Theophylact draws attention to the details provided only by Mark.

In the pericope about picking grain on the Sabbath (Mark 2:23-28), ${ }^{31}$ only Mark gives the name of the high priest. Theophylact notes that the Evangelist calls him Abiathar, while the Book of Kings calls him Abimelech. The Bishop of Ohrid explains that either the high priest had two names or there were two people: the priest Abimelech and the high priest Abiathar. Dealing with this discrepancy, Theophylact gives an explanation which harmonizes the Gospel of Mark with the Book of Kings.

Explaining the pericope about the death of John (Mark 6:17-20), ${ }^{32}$ Theophylact states that at this point Mark "inserts - taking the opportunity - a story about the death of the Baptist." While he does not specify what "occasion" he is referring to, it is probably the earlier mention of Herod's words about the beheading of John (Mark 6:16). ${ }^{33}$

In the commentary on the pericope about the capture of Jesus (Mark 14:43-49), ${ }^{34}$ Theophylact draws attention to the expression "one of those standing," which occurs only in Mark and is used to describe the one who struck the high priest's servant and cut off his ear. The Bishop of Ohrid states that it refers to Peter, while Mark remained silent in order not to glorify his teacher as jealous of Christ. Such an explanation is probably in harmony with the Gospel of John, which identifies Peter as the one who cut the ear (John 18:10-11) and, at the same time, distances itself from the content of Markan Gospel, in which there is nothing about the motivation of Peter (or the evangelist himself). Despite this fact, Theophylact in his commentary refers to the expression found only in the Markan Gospel.

\footnotetext{
31 Theophylactos, Enarratio in Evangelium Marci (PG 123, 517-520).

32 Theophylactos, Enarratio in Evangelium Marci (PG 123, 522).

33 The story of John's death (Matt 14:3-12) in the Gospel of Matthew is also preceded by a statement by Herod (Matt 14:1-2), who only states that John was raised from the dead, and therefore the powers are active in him (Matt 14:2). Meanwhile, according to Mark, Herod tells how John died and who perpetrated it: "the one whom I beheaded" (Mark 6:16). Thus, the connection between Herod's statement and the story of John's death is stronger in Mark than in Matthew.

34 Theophylactos, Enarratio in Evangelium Marci (PG 123, 656-657).
} 


\section{References to Content Specific to Mark}

Theophylact comments on the Gospel of Mark not only by comparing it with others or clearly drawing attention to its origin from Mark. In the Explanation of the Gospel of Mark, he repeatedly ${ }^{35}$ refers to the content existing only in the Gospel of Mark.

\subsection{Comments on Pericopes without Synoptic Parallels}

Theophylact broadly comments on the pericopes which do not have synoptic parallels: the parable of sowing (Mark 4:26-29), the pericope about the healing of the deaf who spoke with difficulty (Mark 7:31-37), the narrative about the healing of a blind man at Bethsaida (Mark 8:22-26) and of a young man clad in linen (Mark 14:50-54).

In the interpretation of the parable of sowing (Mark 4:26-29), ${ }^{36}$ Theophylact shows the allegorical meaning of all the elements of the parable (e.g. "God's kingdom," "man," "seed thrown to earth," "sleep," "getting up at night" and "getting up at day," "sickle" and "harvest," as well as the stages of grain growth). The Bishop of Ohrid does not merely indicate that the people themselves are the earth, although he does say that "we bear fruit by ourselves." The only difference between the parable and Theophylact's interpretation is the harvest time. Mark states that harvest occurs when the condition of the grain allows it (Mark 4:29). According to Theophylact, by contrast, the fruits are picked "when summer allows," and the harvest is the time of the end..$^{37}$

In the commentary on the pericope of the healing of the deaf who spoke with difficulty (Mark 7:31-37), ${ }^{38}$ Theophylact refers to the details of the narrative: distance from the crowd, spitting and touching the tongue, looking to heaven, the prohibition on speaking and its nonadherence. The Bishop of Ohrid points out that the cause of the disease was a demon, which cannot be found in the Gospel of Mark. Perhaps such an explanation arose under the influence of the story about healing after the descent from the Mount of the transfiguration (Mark 9:14-29), in which the child's illness is caused by "a dumb and deaf spirit." Theophylact, explaining it in this way, moves away from Mark's narrative. However, in other aspects of the commentary on this pericope, he remains faithful to it, despite its similarities to the next narrative about healing. Theophylact gives different explanations for the common elements of the pericopes about the deaf who spoke with difficulty (Mark 7:31-37) and the blind man (Mark 8:22-26), the causes of healing in private, the spitting, and the prohibition on speaking.

\footnotetext{
35 Almost fifty such fragments have been found.

36 Theophylactos, Enarratio in Evangelium Marci (PG 123, 533-536).

37 Perhaps the mention of summer was created under the influence of Mark 13:19 (and the parallel passages of Matt 24:32 and Luke 21:30), in which just as the proximity of the summer is recognized from the state of plants, the nearness of the coming of the Son of Man is to be recognized from certain events. 
In the explanation of the pericope about the healing of the blind man at Bethsaida (Mark 8:22-26), ${ }^{39}$ Theophylact firstly states that "Bethsaida suffered great unbelief, and therefore Christ calls her unhappy," This is confirmed by the quotation from Matthew: "Woe to you, Chorazin, woe to you, Bethsaida, for if the miracles that had happened in you had been done in Tire and Sidon, they would have been converted long ago" (Matt 11:21). Then, however, he goes back to the details of Mark's narrative: taking out of the village, spitting in the eyes, laying on hands, partial healing, the prohibition on entering the village and saying what happened (the latter is found only in the Byzantine text).

Theophylact, commenting on Mark 14:50-54, deals with the identity of the young man dressed in linen. ${ }^{40}$ He states that he was probably from the house where Jesus and his disciples ate the Passover. He adds that, according to some, it was James, the Lord's brother, called the Righteous, because he had one garment all his life. The link with James is based on Mark's text, which characterizes the young man as wearing only the linen which he left while running away.

\subsection{Quoting Fragments of Mark's Gospel in the Explanation}

Theophylact, commenting on the pericopes with synoptic parallels, mentions their fragments in a form consistent with the Gospel of Mark.

In the explanation of the fragment of the pericope about the healing of the demented one in the land of the Gerasenes (Mark 5:14b-20), ${ }^{41}$ Theophylact points out that Jesus does not say to the healed person: "Tell how many things I have done to you," but "how many things the Lord has done to you." ${ }^{42} \mathrm{He}$ avoids here harmonization with the parallel of Luke: "Tell how many things God has done for you" (Luke 8:39).

In the commentary to the pericope about the presence of Jesus and the disciples in the vicinity of Dalmanutha (Mark 8:10-12), ${ }^{43}$ Theophylact states that the pharisees are looking for a sign from heaven, but Jesus does not obey them, because the signs they are looking for ${ }^{44}$ will accompany his second coming. The Bishop of Ohrid adds that the first coming of Jesus is full of gentleness, and therefore a sign from heaven was not given to this generation. Theophylact comments in accordance with Mark's text, because the synoptic parallels (Matt 12:39; 16:4; Luke 11:29) mention that no

39 Theophylactos, Enarratio in Evangelium Marci (PG 123, 572-573).

40 Theophylactos, Enarratio in Evangelium Marci (PG 123, 657).

41 Theophylactos, Enarratio in Evangelium Marci (PG 123, 541).

42 Regarding the Gospel of Mark, the pericope quoted before the explanation has only a different order of

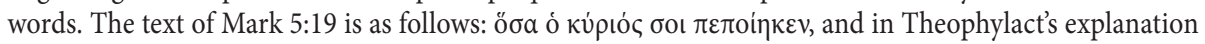

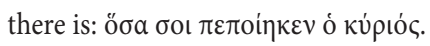

43 Theophylactos, Enarratio in Evangelium Marci (PG 123, 569-572).

44 Theophylact enumerates these signs probably under the influence of the mention of the coming of the Son of Man (Mark 13:24-26). 
sign will be given except the sign of Jonah, and Theophylact only announces a sign from heaven and does not refer to this prophet.

In turn, commenting on the reaction of Jesus to the indignation of the ten caused by the request of the sons of Zebedee (Mark 10:41-45), ${ }^{45}$ Theophylact repeats a detail present only in Mark: "being the servant of all." Mark and Matthew convey the first part of Jesus' statement almost identically (they only have a different order of words) ${ }^{46}$ However, they convey the condition to be met by the one who wants to be first differently. According to Matthew, he is to be "your servant," and according to Mark: "a servant of all." Theophylact explains this according to the text of Mark. He points out that the disciples of Jesus who want to be great, let them serve everyone, because "a great soul is characterized by enduring everything and being the servant of everyone."

\subsection{References to the Details of Mark's Narration}

In his commentary on the Gospels of Mark, Theophylact refers to details which are not present in the other Gospels.

Theophylact, in the commentary on the pericope on numerous healings in the evening (Mark 1:32-34), ${ }^{47}$ points out that the double term which described the time of the day - "when evening has come, when the sun has gone down" (Mark 1:32) - aims to draw attention to this phenomenon. According to Theophylact, it was believed that no one was allowed to heal on the Sabbath, so sunset was awaited, because only then the sick could be brought to be healed. Theophylact accurately draws attention to the function of this expression, important for the narrative, which does not occur in parallel places in the synoptics. ${ }^{48}$ However, the issue of healing as violating the Sabbath has not appeared in the Gospel yet, and in the commented pericope, the inhabitants of Capernaum are those who do not want to violate the Sabbath rest by carrying burdens.

Theophylact explains separately the pericope about people's behavior towards Jesus (Mark 3:6-12). ${ }^{49}$ In comparison with the parallel pericopes (Matt 12:9-14; Luke 6:6-11), only Mark mentions the followers of Herod ${ }^{50}$ At the beginning, the Bishop of Ohrid explains that the Herodians are either Herod's soldiers or the new party

\footnotetext{
45 Theophylactos, Enarratio in Evangelium Marci (PG 123, 608).

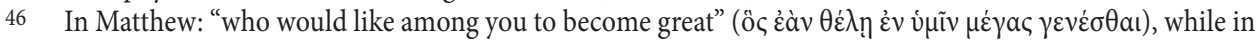

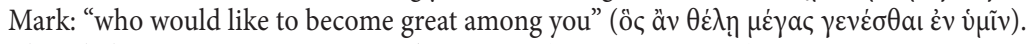

47 Theophylactos, Enarratio in Evangelium Marci (PG 123, 505-508).

48 The Gospel of Matthew in the parallel pericope (Matt 8:16-17) does not include this scene in the time of the Sabbath.

49 Theophylactos, Enarratio in Evangelium Marci (PG 123, 521-524).

50 The Herodians in Mark's narrative are representatives of the political power who, in collaboration with religious authorities, led to the death of Jesus, cf. Guelich, Mark 1-8:26, 138-139.
} 
that regarded Herod as the Messiah and therefore wanted to remove the Lord. Then, Theophylact recalls the expression found only in the Markan Gospel, and by defining the purpose of Herodians' actions, he remains faithful to the Gospel. ${ }^{51}$ Interestingly, Theophylact does not comment on Mark 3:6 as closing the pericope on the healing of a man with a limp hand (Mark 3:1-5) but explains it together with the following narrative about the influx of crowds (Mark 3:6-12). Thus, in the interpretation of Theophylact, the behavior of the Pharisees and Herod's followers is juxtaposed with the behavior of the crowd. The Bishop of Ohrid notes that Jesus is persecuted by those of the same nation, while strangers are grateful to him. Moreover, strangers come to Jesus from afar, while the Jews persecute Jesus, who comes to them. Such an explanation is an example of Theophylact's analysis, which is close to the contemporary synchronic approach.

\section{Conclusion}

The article discusses the issue of how Theophylact of Ohrid relates to the contents of the Markan Gospel in the Explanation of the Gospel of Mark. Firstly, it outlines the comments in which Theophylact harmonizes parallel pericopes to show that the differences between them do not indicate contradictions in the Gospel. Moreover, it includes the analyses of the explanations in which Theophylact discusses the differences between the parallel pericopes and does not unify them. Then, the article presents the places of the Explanation in which Theophylact refers to the author of the Second Gospel. Finally, it highlights comments which refer to words, phrases, and expressions found only in the Gospel of Mark. Among the explanations discussed, there are those in which Theophylact moves away from the content of Mark or approaches the Gospel of Matthew. In other comments, however, the Bishop of Ohrid aptly recognizes the specificity of the Markan Gospel and gives apt explanations.

The above-presented analysis shows how Theophylact relates to Mark's text and its specificity. Theophylact recognizes the theological unity of the four Gospels. He states that they describe the same events but in different ways. This does not mean that they are contradictory, but in this way the stories complement each other. At the same time, he distinguishes Mark's theology from those of other Gospels. This is particularly revealed in frequent comparisons of Mark's pericopes with parallel texts of the other Gospels. Theophylact refers to the content typical of the Gospel of Mark in many places of the Explanation. His attentiveness to the details of

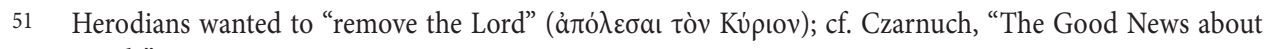
Death," 154-156. 
the narrative is evidenced by the accurate presentation of divergences and, regarding some pericopes, lack of harmonization.

The article broadens the knowledge of biblical hermeneutics, especially the history of the interpretation of the Gospel of Mark. The widespread belief in the influence of Catena in Marcum and John Chrysostom's interpretation of Matthew on Theophylact causes the neglect of the value of the comments of the Bishop of Ohrid. He is accused of lack of thought, originality and compilation. So far, it has not been noticed that it was precisely Theophylact who was the first great commentator on Mark, not because of the values for diachronic exegesis but for values appreciated by synchronic and theological approaches. His recognition of the equal rank of the Markan Gospel made it possible to depart from the traditional preferences for Matthew and John over Mark.

It is advisable, apart from the characteristics of his exegesis, to juxtapose the Explanation with the sources on which it depends, to precisely define the originality of Theophylact as a commentator of the Markan Gospel. A careful comparison can also show which of the similarities can be attributed to real dependence and which result from the adoption of the same assumptions and of the same method.

Accordingly, Theophylact is the first author who should be examined in the studies on the connections between the commentaries on the four Gospels. The Gospel of Mark has already taken its rightful place in contemporary exegesis. Now it is Theophylact, the first man who comments on the whole Markan Gospel in Greek, who awaits similarly adequate appreciation.

Translated by Edyta Gryksa

\section{Bibliography}

Brown, A.J., "The Gospel Commentary of Theophylact, and a Neglected Manuscript in Oxford," Novum Testamentum 49 (2007) 185-196.

Czarnuch, M., "The Good News about Death: Predications of Jesus' Death in the First Commentaries on the Gospel of Mark," Scripta Classica 12 (2015) 151-166.

Czarnuch, M., "Papuga Złotoustego? Teofylakt z Ochrydy jako komentator Ewangelii Marka," Szkice o antyku. I. Antyk odczytany na nowo (eds. A. Kucz - P. Matusiak) (Katowice: Wydawnictwo Uniwersytetu Śląskiego 2014) 31-40.

Czarnuch, M., Ewangelia Marka w komentarzu Teofylakta (Tarnów: Biblos 2018).

Guelich, R.A., Mark 1-8:26 (Dallas: Nelson 1989).

Ioannes Chrysostomus, Commentarius in Sanctum Matthaeum Evangelistam, Homilia 29,1: Patrologiae cursus completus. Series Graeca (ed. J.P. Migne) (Paris: Migne 1862) 57, 357-362.

Malina, A., "Dlaczego Jezus był ze zwierzętami (Mk 1,13)? Odniesienia do zwierząt w Ewangelii Markowej," Verbum Vitae 32 (2017) 233-254. 
Stade, C. (ed.), The Explanation of the Holy Gospel According to Matthew by Blessed Theophylact, Archbishop of Ochrid and Bulgaria (House Springs. MO: Chrysostom Press 2008).

Stade, C. (ed.), The Explanation of the Holy Gospel According to Mark by Blessed Theophylact, Archbishop of Ochrid and Bulgaria (House Springs, MO: Chrysostom Press 2008).

Stade, C. (ed.), The Explanation of the Holy Gospel According to Luke by Blessed Theophylact, Archbishop of Ochrid and Bulgaria (House Springs, MO: Chrysostom Press 2007).

Stade, C. (ed.), The Explanation of the Holy Gospel According to John by Blessed Theophylact, Archbishop of Ochrid and Bulgaria (House Springs, MO: Chrysostom Press 2007).

Theophylactos, Enarratio in Evangelium Marci: Patrologiae cursus completus. Series Graeca (ed. J.P. Migne) (Paris: Migne 1864) 123, 487-682.

Theophylactos, Enarratio in Evangelium Matthaei: Patrologiae cursus completus. Series Graeca (ed. J.P. Migne) (Paris: Migne 1864) 123, 139-486. 